\title{
High levels of variation in Salix lignocellulose genes revealed using poplar genomic resources
}

\author{
Aude C Perdereau ${ }^{1,2,4^{*}}$, Gerry C Douglas', Trevor R Hodkinson ${ }^{2,4}$ and Colin T Kelleher ${ }^{3}$
}

\begin{abstract}
Background: Little is known about the levels of variation in lignin or other wood related genes in Salix, a genus that is being increasingly used for biomass and biofuel production. The lignin biosynthesis pathway is well characterized in a number of species, including the model tree Populus. We aimed to transfer the genomic resources already available in Populus to its sister genus Salix to assess levels of variation within genes involved in wood formation.

Results: Amplification trials for 27 gene regions were undertaken in 40 Salix taxa. Twelve of these regions were sequenced. Alignment searches of the resulting sequences against reference databases, combined with phylogenetic analyses, showed the close similarity of these Salix sequences to Populus, confirming homology of the primer regions and indicating a high level of conservation within the wood formation genes. However, all sequences were found to vary considerably among Salix species, mainly as SNPs with a smaller number of insertions-deletions. Between 25 and 176 SNPs per kbp per gene region (in predicted exons) were discovered within Salix.
\end{abstract}

Conclusions: The variation found is sizeable but not unexpected as it is based on interspecific and not intraspecific comparison; it is comparable to interspecific variation in Populus. The characterisation of genetic variation is a key process in pre-breeding and for the conservation and exploitation of genetic resources in Salix. This study characterises the variation in several lignocellulose gene markers for such purposes.

Keywords: Cellulose, Diversity, Lignin, Populus, Salix, SNPs, Cloning

\section{Background}

The Salicaceae family includes species important for biomass production in the Salix (willow) and Populus (poplar) genera. Salix comprises about 350-500 species [1] and is distributed over wide ecological and climatic zones ranging easterly from North America to China, excluding Australasia. Salix species show considerable variation in size, growth form and crown architecture, ranging from small dwarf shrubs in subgenus Chamaetia, middle-size shrubs in subgenus Vetrix, to the tree willows in subgenus Salix [2]. Demand for energy from renewable sources has provided a new impetus to growing willows in short-rotation coppice (SRC) plantations for bioenergy

\footnotetext{
* Correspondence: perderea@tcd.ie

'Teagasc, Agriculture and Food Development Authority, Kinsealy Research Centre, Malahide Road, Dublin, D17, Ireland

${ }^{2}$ Botany Building, School of Natural Sciences, Trinity College Dublin, Dublin, D2, Ireland

Full list of author information is available at the end of the article
}

production because willow has the ability to grow fast without high maintenance or fertilizer input. Willow has the potential of producing energy that is greater than carbon neutral [3] and as such is seen as being a potential component of a green-house-gas reduction strategy [4].

Wood is one of the most important natural and renewable sources of energy and is therefore an important cost-effective alternative to burning fossil fuels. Lignin is one of its major components (25-35\%) whose calorific value is similar to coal [5]. The evolution of lignin deposition is considered to be one of the key events during the evolution of primitive vascular plants [6,7]. Lignin has been one of the most intensively studied subjects in plant biochemistry for more than a century [8] and, consequently, the enzymes and processes of its biosynthesis pathway are well characterized [9]. Cellulose composes a greater proportion of plant cell walls than lignin, and is the world's most abundant biopolymer [10]. The pathway leading to cellulose biosynthesis in higher plants is also well characterized. 
A number of studies have resulted in the publication of over 1,000 full-length or partial cellulose synthase (CesA) cDNAs or genes from representatives of many plants including cereals, fruits, or trees [11]. Little is known about sequence variation in the genes involved in these pathways especially in Salix. An understanding of sequence variation and potential genetic markers in these genes would be valuable for breeders and pre-breeders of Salix crops such as those for biomass and biofuel.

Willow's closest relative, Populus, has a wealth of genomic resources including a complete genome sequence [12], physical and genetic maps [13,14], over 450,000 expressed sequence tags (ESTs) and thousands of full length cDNAs for a variety of genes. Assays have been developed to amplify poplar genes involved in disease resistance and wood formation [15-17]. A high degree of synteny between Salix and Populus genomes has been demonstrated, and the transfer of molecular markers between these genera has been achieved $[18,19]$.

Specific genes in the lignin and cellulose biosynthesis pathways have been studied in poplar [15,20-22] but very little has been published on such candidate genes in Salix. A few studies have assessed the diversity of breeding collections and natural populations [23,24]. A number of studies have characterized genetic diversity for biomass willows [25] and developed markers for population genetic and breeding purposes [23]. Some have characterized ploidy in different species of Salix [26] and some have assessed species identity and classification [27]. These studies have tended to use either neutral or anonymous markers, as opposed to the approach in the current study, which involves targeting gene regions of known function. Little is known about genetic diversity within specific coding regions of the genome and especially in those regions responsible for wood formation. The monoploid chromosome number is 19, although many species are tetraploid and higher ploidy levels are also common [26,28].

In order to develop single nucleotide polymorphism (SNP) markers for future breeding efforts, we assessed 27 partial genes on a sample of 40 willow genotypes. We tested a broad range of species and varieties to enable greater scope to characterise variants across the genus. These samples include species from the three subgenera of Salix, nine commercial clones and six varieties from commercial basket makers. Genes assayed included those for lignin, cellulose and sucrose biosynthesis, growth hormone regulation, and transcription factors involved in lignin biosynthesis regulation. We tested the utility of Populus derived polymerase chain reaction (PCR) primers for amplification and sequencing of orthologous gene regions in Salix species. We aimed to quantify variation in these genes among Salix species. This is the first characterisation of nucleotide polymorphism from coding and non-coding regions for a set of lignocellulose genes in
Salix species. These data can be used as an aid to decision making in selecting species and strains of willow for future breeding and growing. Polymorphisms and SNPs have potential to be used in selecting pre-breeding material and in association studies to link genotypic variants with specific phenotypes of interest.

\section{Results}

\section{SNP discovery}

After screening of the 27 loci using the primers designed from Populus species alignments [17], six loci showed one clear unique band following agarose gel electrophoresis in multiple samples (from 19 to 40 samples). The PCR conditions on seven other primers were changed by increasing the temperature and decreasing the time of the annealing step, to bring about a single band amplification. The amplicons were the same length as poplar in almost every case, from 411 to $1,204 \mathrm{bp}$. Further analysis was not carried out on the 14 genes that did not amplify successfully. Among them, nine failed to amplify and five showed multiple bands (See Additional file 1).

From this initial PCR (with very little optimisation), twelve loci that gave a strong single-band amplification were selected for sequencing in the Salix samples without cloning. These included genes in the lignin pathway (4CL2, C3H1, C4H, HCT, PAL1, SAD), genes for other wood components (CesA1, CesA2 - cellulose synthase genes, Kor1 - Korrigan), growth related genes (GA-20) and transcription factors (Mybr2r3, Knat7). However, out of these 12 loci, only eight yielded clear sequence traces (C3H1, C4H, PAL1, SAD, CesA1, CesA2, Kor1, Knat7). In order to further validate the results from the approach based on direct sequencing of PCR products from genomic DNA, PCR products from several loci were cloned. The regions cloned included amplicons of 4CL2, CAD, CesA1, GA-20, Knat7, Kor1, Mybr2r3 and SAD in a sample of genotypes including Salix aurita, S. caprea, S. cinerea 'Tricolor', S. herbacea, S. x smithiana, S. viminalis, the commercial clone 'Tora' and Populus tremula. In every case, transformed colonies were obtained successfully. A DNA insert was present in at least $50 \%$ of the cases. The products were sequenced as previously described.

BLAST (Basic Local Alignments Search Tool) searches against the NCBI GenBank database (http://blast.ncbi.nlm. nih.gov) and against Phytozome (www.phytozome.net) were performed on every sequence to test its identity. In all cases the target sequence was the top hit in the search results. BLAST results gave hits to several poplar species like P. alba L., P. balsamifera L., P. deltoides W. Bartram ex Marshall, P. maximowiczii Henry, P. nigra L., P. tremula L., P. tremuloides Michx., P. trichocarpa Torr. \& A. Gray, and $P$. tomentosa Carrière.

In order to test for possible paralogous amplification, further analyses were performed. For each gene, a phylogenetic 
reconstruction was performed (Figure 1). In every generated tree, the Salix consensus sequence was grouped with the targeted gene model with $80 \%$ or higher bootstrap support, thus indicating, in combination with the BLAST results that analogs and not paralogs were amplified.

From the 12 amplicons that were selected for sequencing and cloning, a maximum length of approximately 7,773 bp was sequenced per genotype. Between 19 and 28 genotypes were studied, for a total of $141,400 \mathrm{bp}$. The sequences were deposited in GenBank, under the accession numbers JQ345525-JQ345685 for the direct sequencing and KC491425-KC491628 for the cloned sequencing.

Multiple sequence alignments showed variability between genotypes; the variation consisted primarily of SNPs, but indels were also detected. Table 1 shows the number of SNPs per kbp among the Salix genotypes, among the Populus species and the total number of SNPs detected between the Salix samples and the $P$. trichocarpa gene model (http://www.phytozome.net/poplar). Exonic and intronic sequences were analysed relative to the latest version of $P$. trichocarpa genome (v3). Details of the number of SNPs per genotype compared to the P. trichocarpa are given in Additional file 2.

The genomic regions investigated consisted of $72 \%$ coding and $28 \%$ non-coding sequences (as obtained from P. trichocarpa genome v3). Between 53 and 176 SNPs/kbp were detected in predicted exons per gene region (Table 1). Between 16 and $96 \mathrm{SNPs} / \mathrm{kbp}$ were discovered within Salix and between 8 and 105 SNPs/kbp within Populus (details of the accessions are given in Table 2). An average of 54 SNPs/kbp was found among commercial clones, 58 among hybrids and 57 among species. These differences were not significant under a $t$-test at a threshold of 5\%. Between 195 and 475 SNPs/kbp were detected in predicted introns per gene region.

The most frequent types of polymorphisms were C-T transitions for coding SNPs (40.5\% of SNPs) and A-T transversions for non-coding SNPs (27.3\%). The least frequent types were A-C and G-T transversions for coding SNPs (7.5\%) and C-G transversions for non-coding SNPs (data not shown).

Between 0 and 22 non-synonymous SNPs were discovered among Salix genotypes per gene region, corresponding to between 0 and $38 \mathrm{SNPs} / \mathrm{kbp}$ (Table 1). Multiple indels were also identified. Among them, only three were located in coding regions. Two were multi-base indels (3 and $8 \mathrm{bp}$ ). One shift of the reading frame was detected in $S A D$ for $S$. herbacea due to an 8 bp insertion at the homozygous state. This was confirmed by cloning where the insertion was detected in every haplotype of $S$. herbacea. A 3 bp insertion was detected in Mybr2r3 for all Salix individuals compared to the reference $P$. trichocarpa and $P$. tremula sequences.

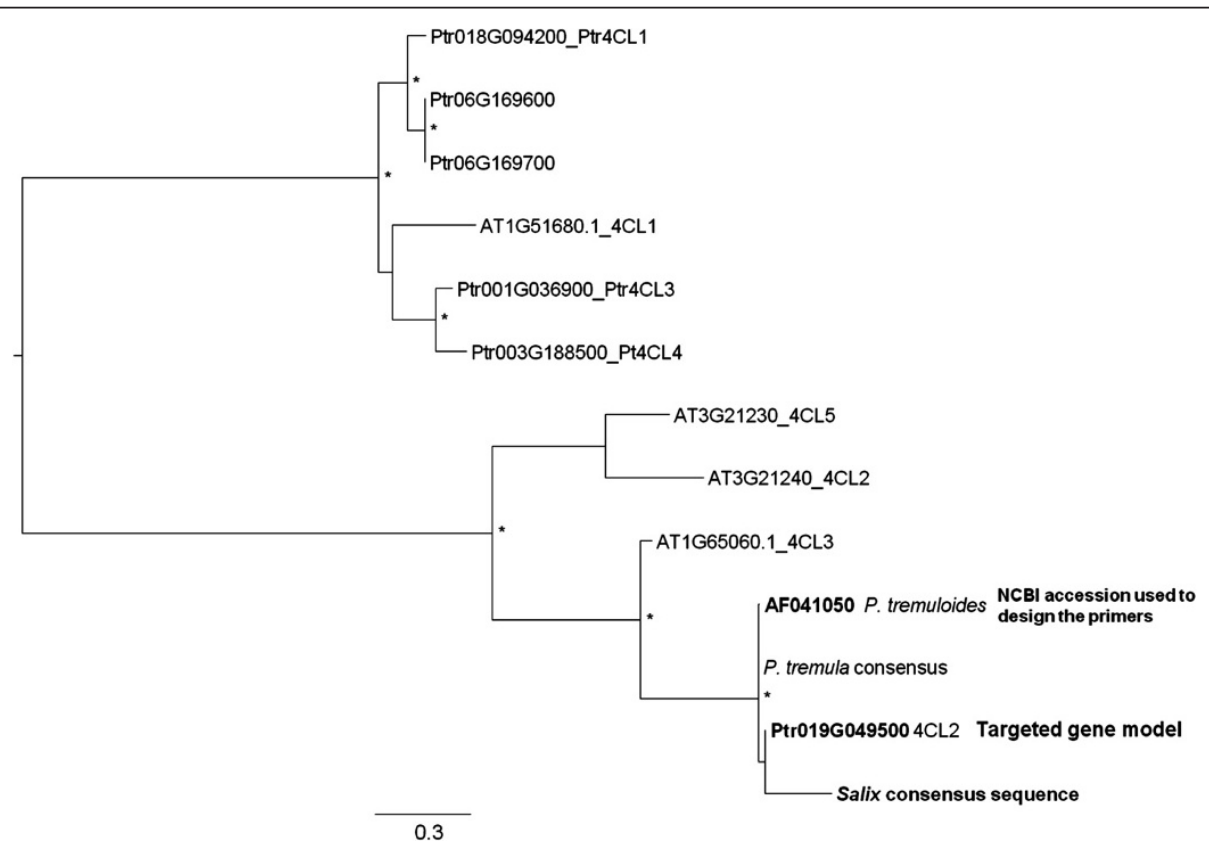

Figure 1 Phylogenetic reconstruction of the genes used in this study. Angiosperm gene family keyword search was performed into Phytozome (www.phytozome.net/search.php) and A. thaliana and P. trichocarpa genes were retrieved and aligned to a consensus Salix sequence generated from our study. Midpoint rooted, bootstrapped trees were generated using maximum likelihood analysis in PhylML 3.0 [29] with HKY85+G substitution model (estimated gamma shape parameter and four substitution rate categories) and NNI branch swapping. Bootstrapping included 1000 replicates with the same model and branch swapping. Asterisks indicate nodes with $80 \%$ or higher bootstrap support (Ptr: P. trichocarpa, AT: A. thaliana). The 4CL2 gene tree is given as an example (NCBI accession: AF041050, Populus tremuloides clone Pt4CL2 4-coumarate: CoA ligase mRNA, complete cds). 
Table 1 Variation for each gene region showing the $P$. trichocarpa gene models used as reference, the number of Salix genotypes and Populus species studied, the total number of SNPs detected, the number of SNPs within Salix and within Populus; the number of insertions/deletions

\begin{tabular}{|c|c|c|c|c|c|c|c|c|c|c|}
\hline Gene region & $\begin{array}{c}\text { P. trichocarpa } \\
\text { reference (Phytozome } \\
\text { gene model) }\end{array}$ & $\begin{array}{l}\text { No. of Salix } \\
\text { genotypes } \\
\text { studied }\end{array}$ & $\begin{array}{l}\text { No. of Populus } \\
\text { species studied } \\
\text { (See Table 2) }\end{array}$ & $\begin{array}{c}\text { Predicted } \\
\text { Exons/ introns }{ }^{\mathrm{a}}\end{array}$ & $\begin{array}{c}\text { Studied } \\
\text { length (bp) }\end{array}$ & $\begin{array}{l}\text { Total SNPs } \\
\text { per kbp }\end{array}$ & $\begin{array}{l}\text { SNPs within } \\
\text { Salix per kbp }\end{array}$ & $\begin{array}{c}\text { SNPs within } \\
\text { Populus per kbp }\end{array}$ & Total Indels & $\begin{array}{c}\text { Total non } \\
\text { synonymous sites } \\
\text { among Salix per kbp }\end{array}$ \\
\hline \multicolumn{11}{|c|}{ A) DIRECT SEQUENCING } \\
\hline \multirow[t]{2}{*}{$\mathrm{C} 3 \mathrm{H} 1$} & Potri.006G033300 & 23 & 5 & Exon & 347 & 118 & 63 & 40 & 0 & 6 \\
\hline & & & & Intron & 0 & / & / & / & / & \\
\hline \multirow[t]{2}{*}{$\mathrm{C} 4 \mathrm{H}$} & Potri.013G157900 & 13 & 6 & Exon & 609 & 76 & 16 & 21 & 0 & 3 \\
\hline & & & & Intron & 0 & / & / & / & / & \\
\hline \multirow[t]{2}{*}{ CesA2 } & Potri.005G194200 & 22 & 4 & Exon & 244 & 53 & 20 & 20 & 0 & 0 \\
\hline & & & & Intron & 87 & 195 & 92 & 11 & 2 & \\
\hline \multirow[t]{2}{*}{ Pal1 } & Potri.006G126800 & 20 & 6 & Exon & 474 & 99 & 46 & 40 & 0 & 0 \\
\hline & & & & Intron & 0 & / & / & / & / & \\
\hline \multirow[t]{2}{*}{ CesAl } & Potri.002G257900 & 20 & 6 & Exon & 629 & 68 & 11 & 38 & 0 & 2 \\
\hline & & & & Intron & 130 & 208 & 146 & 31 & 3 & \\
\hline \multirow[t]{2}{*}{ Knat7 } & Potri.001G112200 & 17 & 2 & Exon & 120 & 25 & 8 & 8 & 0 & 0 \\
\hline & & & & Intron & 95 & 284 & 221 & 42 & 3 & \\
\hline \multirow[t]{2}{*}{ Kor1 } & Potri.003G151700 & 23 & 5 & Exon & 192 & 63 & 10 & 36 & 0 & 0 \\
\hline & & & & Intron & 117 & 179 & 111 & 17 & 0 & \\
\hline \multirow[t]{2}{*}{$S A D$} & Potri.016G078300 & 15 & 4 & Exon & 395 & 142 & 78 & 30 & 1 & 28 \\
\hline & & & & Intron & 19 & 158 & 0 & 158 & 0 & \\
\hline \multicolumn{11}{|c|}{ B) COMBINED RESULTS (from direct sequencing and cloning) } \\
\hline \multirow[t]{2}{*}{ CesAl } & Potri.002G257900 & 20 & 6 & Exon & 629 & 107 & 33 & 54 & 0 & 14 \\
\hline & & & & Intron & 130 & 315 & 177 & 46 & 8 & \\
\hline \multirow[t]{2}{*}{ Knat7 } & Potri.001G112200 & 17 & 2 & Exon & 372 & 70 & 38 & 30 & 0 & 13 \\
\hline & & & & Intron & 392 & 209 & 117 & 56 & 15 & \\
\hline \multirow[t]{2}{*}{ Kor1 } & Potri.003G151700 & 23 & 5 & Exon & 319 & 94 & 38 & 34 & 0 & 19 \\
\hline & & & & Intron & 438 & 201 & 98 & 23 & 11 & \\
\hline \multirow[t]{3}{*}{$S A D$} & Potri.016G078300 & 15 & 4 & Exon & 582 & 165 & 93 & 24 & 1 & 38 \\
\hline & & & & Intron & 217 & 475 & 207 & 69 & 4 & \\
\hline & & & & C) CLONING & & & & & & \\
\hline \multirow[t]{2}{*}{$4 C L 2$} & Potri.019G049500 & 7 & 2 & Exon & 249 & 116 & 48 & 8 & 0 & 20 \\
\hline & & & & Intron & 289 & 325 & 83 & 35 & 14 & \\
\hline
\end{tabular}


Table 1 Variation for each gene region showing the $P$. trichocarpa gene models used as reference, the number of Salix genotypes and Populus species studied, the total number of SNPs detected, the number of SNPs within Salix and within Populus; the number of insertions/deletions (Continued)

\begin{tabular}{|c|c|c|c|c|c|c|c|c|c|c|}
\hline \multirow[t]{2}{*}{$G A-20$} & Potri.015G134600 & 6 & 2 & Exon & 620 & 176 & 58 & 105 & 0 & 27 \\
\hline & & & & Intron & 290 & 462 & 117 & 210 & 31 & \\
\hline \multirow[t]{2}{*}{$C A D$} & Potri.009G095800 & 7 & 2 & Exon & 439 & 125 & 96 & 16 & 1 & 34 \\
\hline & & & & Intron & 436 & 273 & 128 & 76 & 21 & \\
\hline \multirow[t]{2}{*}{ Mybr2r3 } & Potri.015G033600 & 6 & 2 & Exon & 351 & 117 & 23 & 26 & 1 & 11 \\
\hline & & & & Intron & 259 & 228 & 108 & 31 & 11 & \\
\hline
\end{tabular}

abased on P. trichocarpa v3 assembly retrieved from Phytozome (www.phytozome.net/poplar).

b(No. total SNPs / length) $\times 1,000$.

${ }^{c}$ (No. SNPs within Salix or within Populus / length) $\times 1,000$

Both direct sequencing and cloning techniques were used. 
Table 2 Salix species, hybrids and commercial clones and Populus accessions that were used in this study

\begin{tabular}{|c|c|c|c|c|c|}
\hline Species/Clone & Subgenus & Source & Source ID & Poplar accessions & NCBI ID \\
\hline S. alba L. var. vitellina L. Stokes & Salix & NBG & 1977.1871 & P. alba $\times$ P. grandidentata & EU391631 (C3H1) \\
\hline S. aurita L. & Vetrix & NBG & 1988.0222 & P. alba $\times$ P. grandidentata & GU324115 (Kor1) \\
\hline S. babylonica L. var. pekinensis 'Tortuosa' & Salix & NBG & 1978.0029 & P. balsamifera $\times$ P. deltoides & AJ438351 (C3H1) \\
\hline S. caprea L. & Vetrix & NBG & 1979.0307 & P. kitakamiensis & D82815 (C4H) \\
\hline S. cinerea L. 'Tricolor' & Vetrix & NBG & 2002.2187 & P. sieboldii $\times$ P. grandidentata & D30656 (Pal1) \\
\hline S. elaeagnos Scop. (= S. incana Schrank) & Vetrix & NBG & 2001.2367 & P. tomentosa & EU760387 (C4H) \\
\hline S. exigua $\mathrm{L}$. & Salix & NBG & 2003.0719 & P. tomentosa & FJ534554 (CesA1) \\
\hline S. fragilis L. & Salix & NBG & 1977.0902 & P. tomentosa & HQ585873 (CesA2) \\
\hline S. glabra Scop. & Vetrix & NBG & $X X .004178$ & P. tomentosa & EU760386 (Pal1) \\
\hline S. gracilistyla Miq. var. melanostachys & Vetrix & NBG & 1976.0659 & P. tremula & EU753093 (C3H1) \\
\hline S. herbacea L. & Chamaetia & Wild collected, Ireland & & P. tremula $\times$ P. tremuloides & AY573571 (CesA1) \\
\hline S. lucida Muhlenb. & Salix & NBG & 1986.0050 & P. tremula $\times$ P. tremuloides & AY573572 (CesA2) \\
\hline S. pentandra L. & Salix & NBG & 1926.004139 & P. tremula $\times$ P. tremuloides & AY660967 (Kor1) \\
\hline S. phylicifolia L. & Vetrix & NBG & 1970.0402 & P. tremula $\times$ P. tremuloides & AY850131 (SAD) \\
\hline S. phylicifolia L. & Vetrix & NBG & 2008.1233 & P. tremuloides & DQ522295 (C4H) \\
\hline S. rehderiana Schneid. & Vetrix & NBG & $X X .004165$ & P. tremuloides & AF527387 (CesA1) \\
\hline S. scouleriana Barr. & Vetrix & NBG & 1984.0752 & P. tremuloides & AY535003 (Kor1) \\
\hline S. viminalis $\mathrm{L}$. & Vetrix & NBG & 2004.0293 & P. tremuloides & AF480619 (Pal1) \\
\hline S. $\mathbf{x}$ chrysocoma Dode (= S. alba L. var. vitellina L. Stokes x S. babylonica L.) & & NBG & $X X .004181$ & P. tremuloides & AF273256 (SAD) \\
\hline S. $\mathbf{x}$ erdingeri Kern ( $=$ S. daphnoides Vill. $\mathbf{x}$ S. caprea L.) & & NBG & 1925.004149 & P. tricho $\times$ P. deltoides & AF302495 (C4H) \\
\hline S. $\mathbf{x}$ erythroflexuosa Rag. (= S. $\mathbf{x}$ chrysocoma $\times$ S. matsudana) & & NBG & 1986.0041 & P. $\mathbf{x}$ canadensis & AM922197 (Pal1) \\
\hline S. x laurina Sm. (= S. caprea L. x S. phylicipholia) & & NBG & 1977.1877 & P. $\mathbf{x}$ canescens (P.tremula $\times$ P.alba) & AF081534 (CesA1) \\
\hline S. $\mathbf{x}$ rubens 'Basfordiana' (= S. alba L. var. vitellina L. Stokes $\mathbf{x}$ S. fragilis L.) & & NBG & $X X .004137$ & & \\
\hline S. $\mathbf{x}$ rubens 'Schrank' (= S. alba L. x S. fragilis L.) & & NBG & $X X .004133$ & & \\
\hline S. x rubens Schrank 'Basfordiana' var. sanguinea & & NBG & 1981.1773 & & \\
\hline S. $\mathbf{x}$ rubra Huds (S. purpurea $\mathbf{x}$ S. viminalis L.) & & NBG & 1981.1520 & & \\
\hline S. $\mathbf{x}$ smithiana Willd. $(=$ S. cinerea $L \mathbf{x}$ S. viminalis $L$.) & & NBG & 2004.0292 & & \\
\hline S. purpurea L. & Vetrix & Joe Hogan & Joe Hogan1 & & \\
\hline S. viminalis $\mathrm{L}$. & Vetrix & Joe Hogan & Joe Hogan2 & & \\
\hline S. viminalis $\mathrm{L}$. & Vetrix & Joe Hogan & Joe Hogan3 & & \\
\hline S. purpurea L. & Vetrix & Joe Hogan & Joe Hogan4 & & \\
\hline
\end{tabular}


Table 2 Salix species, hybrids and commercial clones and Populus accessions that were used in this study (Continued)

\begin{tabular}{|c|c|}
\hline 'Sven': S. viminalis L. x (S. schwerinii x S. viminalis) & Svalöf Weibull (Sweden) \\
\hline 'Inger': S. triandra x S. viminalis & Svalöf Weibull \\
\hline 'Tordis': (S. schwerinii x S. viminalis) x S. viminalis & Svalöf Weibull \\
\hline \multicolumn{2}{|l|}{ 'Endurance' } \\
\hline 'Tora': S. schwerinii x S. viminalis & Svalöf Weibull \\
\hline 'Resolution': (S. viminalis $\mathbf{x}$ (S. schwerinii $\mathbf{x}$ S. viminalis)) $\mathbf{x}$ (S. viminalis $\mathbf{x}$ (S. viminalis $\mathbf{x}$ S. schwerinii)) & UK (European) \\
\hline 'Doris': S. dasyclados & Sweden \\
\hline 'Terra Nova': (S triandra x S. viminalis) x S linderstipularis & UK (European) \\
\hline 'Torhild': (S. schwerinii x S. viminalis) x S. viminalis & Svalöf Weibull \\
\hline P. tremula L. & Wild collected, Ireland \\
\hline
\end{tabular}


A deletion of one bp was also detected in $C A D$ for one haplotype of Salix 'Tora'.

All the SNPs of CesA1, Knat7, Kor1, and SAD found from direct sequencing of amplicons from genomic DNA were confirmed by analysis of the sequences from the cloned amplicons. In addition, more SNPs were found in the cloned compared to the uncloned sequences (see Table 1B). This was as a result of an increase in the length of the sequences obtained from cloned PCR products and the fact that haplotypes could be resolved. When the same length is studied, 38 more SNPs were discovered in CesA1, 5 for Knat7, 13 for Kor1, and 15 for SAD. Between 400-500 more bp were sequenced via the cloning approach except for CesA1 where the same length was observed. Therefore, 78 more SNPs in total were discovered for Knat7, 85 for Kor1, and 140 for SAD (data not shown). Cloning also allowed a better resolution of the indels, as between 4 and 12 more indels were found (all located in predicted non-coding regions).

A different sequence length was obtained for all cloned PCR products of $S$. viminalis, $S$. X smithiana and for one sequence of Salix 'Tora' for the SAD gene region. Indeed, sequences of c. 1,030 bp were obtained for these sequences compared to c. $800 \mathrm{bp}$ for the other cloned individuals. Thus an additional 230 bp was obtained towards the end of the sequence after the last predicted intron and this was very different from the reference sequence.

Many indels were found in 4CL2, CAD, GA-20 and $M y b r 2 r 3$, and this was the main reason why the sequences were not analysable without the cloning step (Table $1 \mathrm{C}$ ). For GA-20, indels at a heterozygous level were found in nearly all the individuals analysed. Between 116 and 176 $\mathrm{SNPs} / \mathrm{kbp}$ were found in total in predicted exons, and between 23 and 96 SNPs/kbp found within Salix. Between 228 and $436 \mathrm{SNPs} / \mathrm{kbp}$ in total were found in predicted introns (Table 1C).

Haplotype number was calculated after the cloning step using Arlequin 3.5. Between 1 and 8 haplotypes were found per individual (Table 3). Salix cinerea 'Tricolor' and S. $\mathrm{X}$ smithiana are polyploids ( $4 \mathrm{x}$ and $3 \mathrm{x}$, respectively). The other genotypes are diploid (Table 3). However, excluding the 2 polyploid genotypes more than 2 haplotypes were found in $70 \%$ of the cases.

In order to further investigate this issue, midpoint rooted, bootstrapped maximum likelihood trees were generated in PhyML for each of the genes. The Knat7 haplotype tree is given as an example (Figure 2). The tree grouped together the different haplotypes of a species in no more groups than the expected ploidy (although these groups were not strongly supported). There was very little difference between the haplotypes. The same pattern was found for the other genes (data not shown).

Regression analysis was used to explore the relationship between DNA ploidy and number of SNPs/kbp on 20 Salix genotypes. It showed that there was a positive correlation between ploidy and the number of scored fragments $\left(\mathrm{F}_{20}=8.94, \mathrm{P}<0.005, \mathrm{R}^{2}=0.34\right)$ (Figure 3).

\section{Phylogenetic trees}

In order to explore similarities or dissimilarities in the data, phylogenetic trees were generated with maximum parsimony in PAUP 4.0 and maximum likelihood in PhyML with HKY85+G. The two types of analysis gave the same results. Therefore only the trees from the PhyML analyses are shown (Figure 4). These trees are based on the eight genes analysed by direct sequencing and the genotypes where most of the sequences were present, with the $P$. trichocarpa gene model and $P$. tremula sequences included (Figure 4A) or excluded to improve resolution around the Salix samples (Figure 4B).

The trees give a visual indication of the genetic variability in the samples analysed. Although fully resolved, the trees are not strongly supported. However, the two poplars are separated from the Salix and the 3 subgenera are recognizable. The four Salix subg. Salix genotypes are grouped together, as well as most of the Salix subg. Vetrix genotypes. All the viminalis type genotypes are grouped together, S. viminalis, the commercial clones, and a hybrid S. cinerea X S. viminalis. Salix herbacea appears to be not so different from the subg. Vetrix genotypes.

Table 3 Number of haplotypes found in Salix

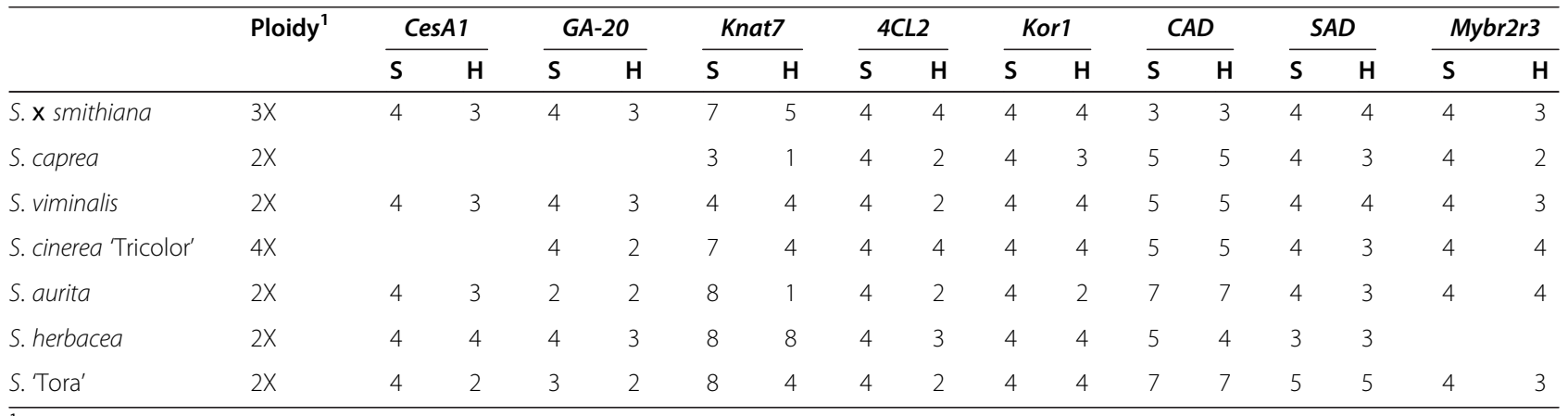

'based from Thibault, 1998 [26] Stamati et al., 2003 [30] and MacAlpine et al., 2008 [31].

( $\mathrm{S}=$ number of sequences analysed, $\mathrm{H}=$ number of haplotypes found). 


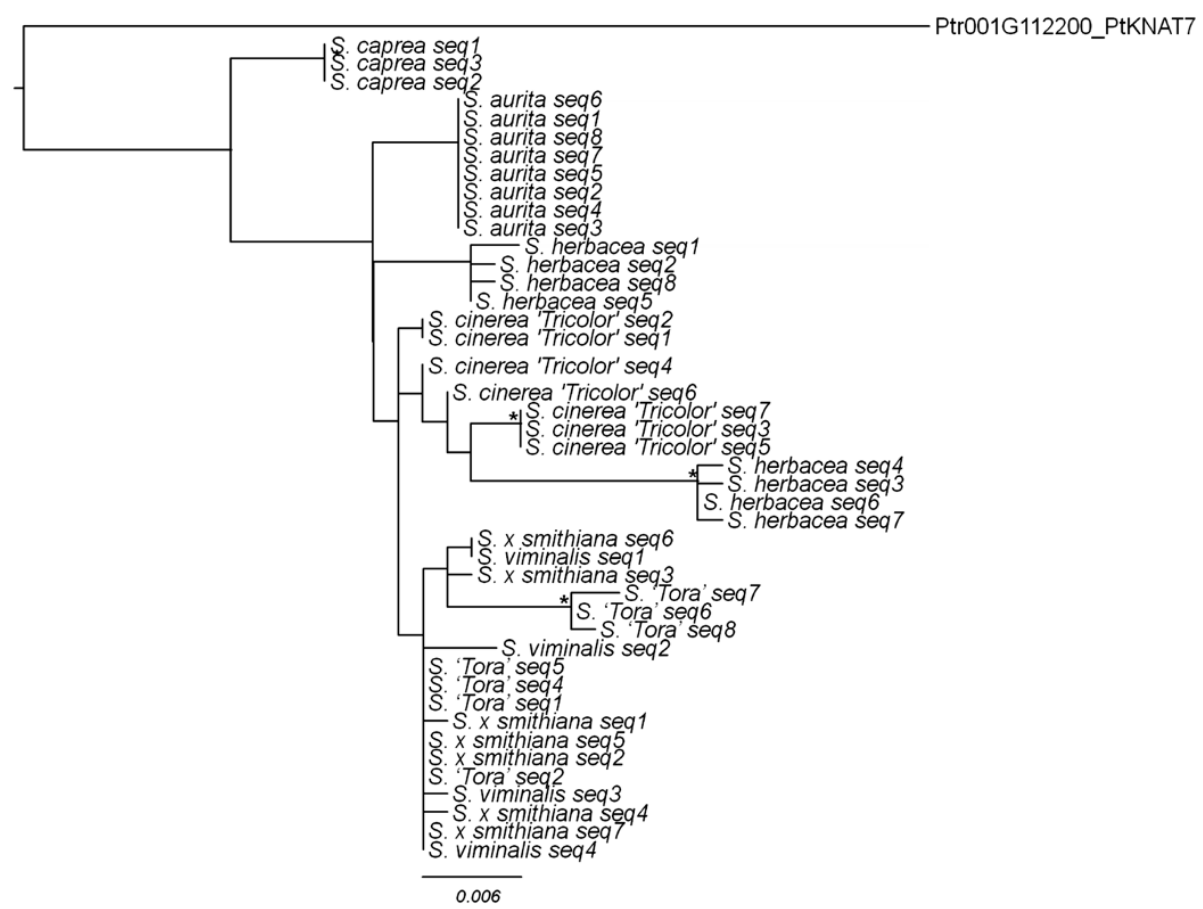

Figure 2 Midpoint rooted, maximum likelood tree of Knat7 haplotypes with bootstrap values generated in PhyML with HKY85+G substitution model. Asterisks indicate branches with $80 \%$ or higher bootstrap support. Knat7 haplotype tree is given here as an example. Ptr001G112200_PtKNAT7: P. trichocarpa; similar to homeodomain transcription factor (KNAT7).

\section{Discussion}

We tested the transferability of Populus genomic resources (a set of PCR primers for multiple lignocellulose genes) to its sister genus Salix and obtained data on the level of sequence variation between and within the genera. Without much PCR optimisation we found that approximately $30 \%$ of the markers developed for Populus tremuloides worked in a broad sample of Salix genotypes. This is based on an approach of direct sequencing of PCR products from genomic DNA amplification in a variety of regions in a large array of genotypes. The cloning step on a set of Salix genotypes was added to validate the direct sequencing approach and to improve resolution of the data. This method was successful on all the genotypes and regions of the genome assayed. It increased the proportion of successful PCRs from 30 to $44 \%$. This means that we can use almost one half of the primers designed for Populus on Salix. This level of transferability will prove very useful for the studies of natural populations of willows and for plant breeding, where marker availability is much lower than in poplar. The relatively low $30 \%$ success rate was partially due to the fact that we tested across such an array of species and genes and it contrasts with other studies that showed greater transferability [18]. It is likely that this rate could be increased with a more limited subset of targets and more optimisation, but for the purposes of this study we decided to focus on the regions that amplified in a majority of species without optimisation.

SNP discovery and transferability of Populus primers to Salix have been studied $[18,19,32,33]$ but these studies were limited to a small number of species, in particular S. viminalis, S. schwerinii, and their hybrids. Studies on multiple Salix species have been done based on AFLP markers or a limited number of sequences from the chloroplast and nuclear ribosomal regions [34-37]. None have so far assessed variation in lignocellulose genes among Salix species.

Kelleher et al. [17] showed the same primers amplified successfully across a variety of Populus species. Here we show a subset also amplifies putative orthologs in Salix. A high level of gene synteny has already been shown between Populus and Salix based on high-density genetic maps $[18,19]$ and the current data confirms the homology of amplicons between these genera in wood and cell wall related genes. In the current study, between 76 and 267 $\mathrm{SNPs} / \mathrm{kbp}$ were discovered in a set of 12 genes. The number of SNPs detected is relatively high compared to other studies $[17,38,39]$, partially because comparisons were made between genera and genotypes and not among individuals of the same species. These SNPs are a potential toolkit for future pre-breeding and will be tested for species specificity. When these data were compared to Populus accessions retrieved from NCBI, similar levels of variation were 


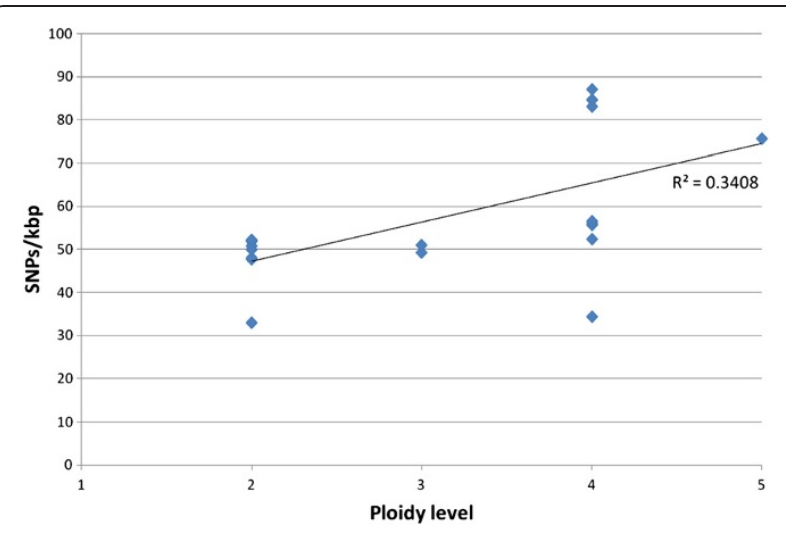

Figure 3 Regression analysis of the putative ploidy level against the number of SNPs/kbp. The trendline and $R^{2}$ are shown.

found among Salix and Populus species. Within Salix, the total variation among commercial clones and hybrids was lower than among species (68 SNPs and 42 SNPs vs 89 SNPs respectively, data not shown), but was not significant under a $t$-test at a threshold of 5\%. These results are consistent with the fact that a narrow genetic pool is often used for breeding willows. For example, the Salix cultivars 'Torhild' and 'Tordis' are half-sibs with 'Tora' as the common female parent. Also the female parent SW930812 of 'Resolution' is a sibling of 'Sven'. The majority of SRC willows currently grown in Europe are interspecific hybrids with some Salix viminalis in the pedigree. This species is favoured for SRC because it grows fast, coppices well and maintains a good growth form [40]. We show that there is a wealth of genetic variation within Salix that is as yet untapped.

Another issue to address is the possible polyploidy of some of the Salix genotypes studied. Suda [41] reported that Salix is one of the few woody genera with a large number of polyploid taxa. A study by Thibault [26] investigated polyploidy in 16 species of Salix including S. alba L. var. vitellina L. Stokes, S. fragilis L., S. cinerea 'Tricolor' and the hybrids $S . \times$ rubens Schrank and $S . \times$ chrysocoma Dode which were shown to be tetraploid. Salix babylonica var. pekinensis 'Tortuosa' has also been shown to be tetraploid [28]. The positive correlation we found between the number of scored markers and ploidy was consistent with results reported in other studies [36].

When levels of variation are compared between Salix and Populus in predicted exons, half of the genes show a trend towards larger diversity in Salix compared to Populus (Pal1, Knat7, Kor1, Mybr2r3, CesA2, C4H) (Figure 5) and the remaining half show the opposite Populus more variable than Salix. For example, the $C A D$ gene is the most variable region in Salix but is one of the least variable in both the species of Populus studied. This could potentially be due to copy-number variation or differential regulation of wood formation in the 2 different genera, but further study is necessary to establish any patterns. Variation was found to be much lower in intraspecific studies of natural populations of $P$. tremula [38,39], where $17 \mathrm{SNPs} / \mathrm{kbp}$ were detected within five nuclear genes [38], 19 SNPs/kbp with 77 gene fragments [39] and $18 \mathrm{SNPs} / \mathrm{kbp}$ in P. tremuloides [17]. However, as the previous studies $[17,38,39]$ are based on intraspecific variation it is understandable that the levels from the current study are much higher - 53 SNPs/kbp in Salix and 30 in Populus in the current study.

From the phylogenetic tree results (Figure 4), differentiation is shown among Salix species. Members of the different subgenera are often grouped together (although not strongly supported). All the commercial clones group close to $S$. viminalis, which is the main species used for willow breeding and thus the clones share sequence similarity with this.

This study also emphasizes that wood formation genes and more particularly the ones involved in the phenylpropanoid metabolism (PAL1, C3H1, C4H, SAD, CAD, $4 C L 2)$ are conserved among two genera in Salicaceae. These results are consistent with a study by Hamberger et al. [42] who discovered considerable conservation among poplar, Arabidopsis, and rice genomes for nine phenylpropanoid gene families. While the genes show a high level of conservation, the difference in the mutation rates as shown in Figure 5 is of interest to understanding the development and evolution of wood formation genes within Salicaceae.

PAL1, C3H1, C4H and 4CL2 genes have relatively few non-synonymous sites $(0,6,3$ and 20 non-synonymous $\mathrm{SNPs} / \mathrm{kbp}$, respectively). These genes are upstream of the lignin pathway $[9,42]$. On the other hand, the $C A D$ and $S A D$ genes have more non-synonymous sites (34 and 38 non-synonymous SNPs/kbp, respectively). CAD enzyme is employed at the end of the monolignol biosynthetic pathway to convert the esters into their corresponding alcohols [43]. According to Li et al. [44], SAD is essential for the biosynthesis of syringyl monolignol and also intervenes at the end of lignin biosynthesis. Our results are consistent with the prediction that selective constraint is progressively relaxed along metabolic pathways [45]. Upstream genes are more pleiotropic, being required for a wider range of end products and thus tend to be more selectively constrained. However, another study on tobacco (Nicotiana tabacum L.) from Barakate et al. [46] has shown that $S A D$ might not be involved in the last step in syringyl monolignol biosynthesis in wood-producing angiosperms. They have shown the existence of $S A D$ in lignifying tissues but are not clear of its function. Moreover, it has also been hypothesized that SAD might be a dehydrogenase that directs monolignol precursors toward plant defense [47], 


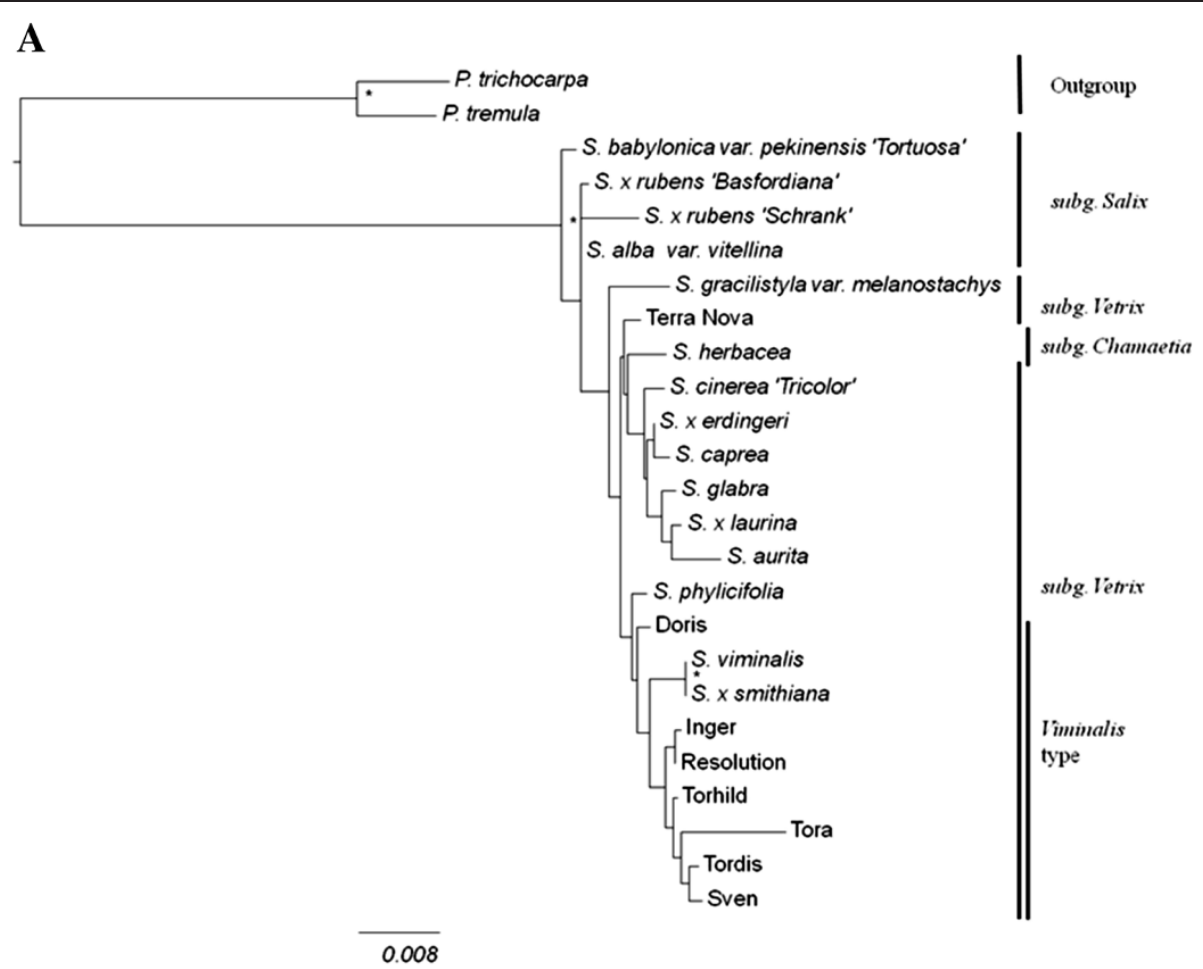

B

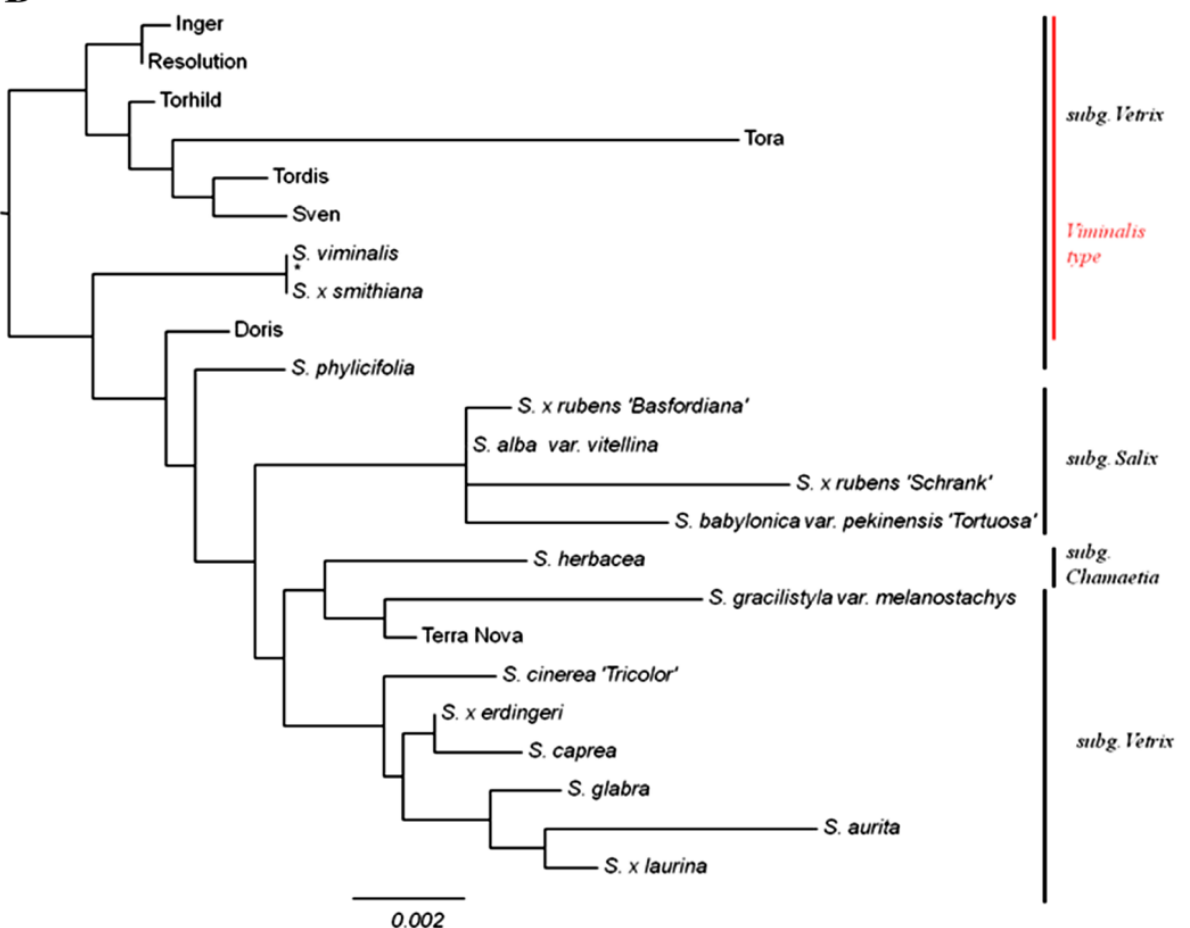

Figure 4 Midpoint rooted, bootstrapped trees based on the eight genes analysed by direct sequencing (and the genotypes where most of the sequences were present) generated using maximum likelihood in PhyML with HKY85+G substitution model. Asterisks indicate nodes with $50 \%$ or higher bootstrap support. The three Salix subgenera (according to most authorities) are indicated. Trees are shown with the $P$. trichocarpa gene model and $P$. tremula sequences included (Figure $4 \mathbf{A}$ ) or excluded (Figure $4 \mathbf{B}$ ). 


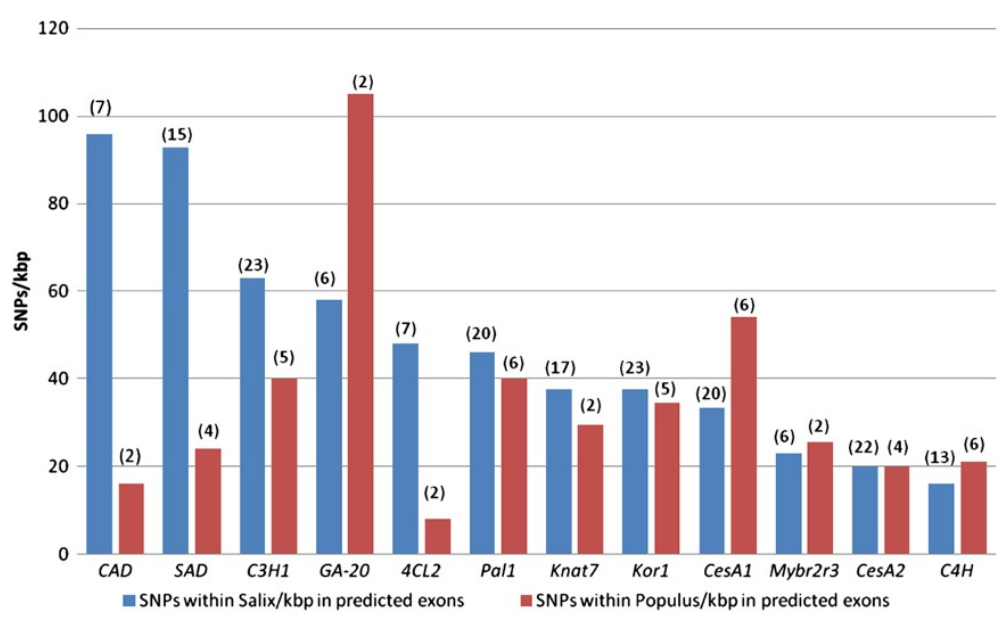

Figure 5 Differences in the levels of SNPs in predicted exons within the genes found in Salix and Populus. The data are ranked based on the levels of variation in Salix. The number of Salix genotypes or Populus species studied is indicated above each column.

which could explain the relaxed selective constraint found in this study.

With the cloning step, more regions have been sequenced and analysed on a subset of samples. It has been shown that orthologs have been amplified with confidence. More SNPs have been discovered than with direct sequencing from non-cloned amplicons. Results for haplotype number determination, by mere counting in Arlequin, gave more than 2 haplotypes in 70\% of the cases for assumed diploid species. The different haplotypes found in each individual were similar except for a few SNPs as emphasized by the haplotype trees. BLAST searches and gene trees revealed that the reference used for the primer design and the targeted Populus gene model were closely related to the Salix sequences so it is most likely that these different haplotypes are not duplicates of another gene family member. Another possible explanation for excess haplotype number is that cloning emphasizes single-base substitution errors during the initial PCR. They are estimated to occur at a rate of $1-7 \times 10^{-4}$ per base pair per cycle [48]. Some variants were possibly generated by enzyme slippage during sequencing especially for homopolymeric regions. It is also possible that some of the taxa, presumed to be diploid, are in fact polyploid.

\section{Conclusion}

We have characterised a large number of new SNP markers for an array of willow species (Salix spp.), in 12 gene regions involved in the lignin and cellulose biosynthesis pathways. The poplar genome sequence and other poplar based resources were used as a reference and the resources were transferred to Salix. This is the first study to quantify levels of nucleotide polymorphism in a wide range of willows for such genes from the three subgenera of Salix. The results show that Salix harbours significant amounts of genetic variation at these loci (both between the different Salix species and between Salix and Populus). The study shows that the markers can be transferred from Populus to Salix in approximately half of the cases and justifies this approach for marker application and development in Salix. The data should be of interest and potential use to future work on pre-breeding programmes or association genetics in Salix.

\section{Methods}

\section{Sample collection and DNA extraction}

Leaf tissue samples from Salix alba L. var. vitellina L. Stokes, S. aurita L., S. babylonica L. var. pekinensis 'Tortuosa', S. caprea L., S. cinerea L. 'Tricolor', S. elaeagnos Scop., S. exigua L., S. fragilis L., S. herbacea L., S. glabra Scop., S. gracilistyla Miq. f. melanostachys (Makino) H. Ohashi, S. lucida Muhlenb., S. pentandra L., S. phylicifolia L., S. rehderiana Schneid., S. scouleriana Barr., and S. viminalis $\mathrm{L}$. were obtained from living specimens at the National Botanic Gardens, Dublin, Ireland. Nine hybrids were also sampled from the Gardens. Samples of commercial clones such as 'Sven,' 'Inger,' 'Tordis,' 'Tora,' 'Resolution,' 'Doris,' 'Terra Nova,' 'Torhild' and 'Endurance' were obtained from Teagasc Kinsealy Research Centre, Dublin, Ireland. Four varieties (mainly S. viminalis and S. purpurea) from an Irish basket maker in Galway completed the list (Table 2). A sample of Populus tremula L. collected from a wild population was also used as a template for the amplifications and sequencing.

Leaves were dehydrated and kept in plastic bags using silica gel. The tissue was disrupted using the Qiagen Tissuelyser II, and DNA was extracted using the DNeasy Plant Mini Kit by Qiagen Ltd. The DNA samples were kept frozen at $-20^{\circ} \mathrm{C}$. The resulting DNA was viewed and assessed for quality and quantity using agarose 
gel electrophoresis, ethidium bromide staining and a UV light.

\section{Gene regions and primer description}

The gene regions tested included those of the lignin biosynthesis and regulation pathways, genes involved in the synthesis of other cell wall compounds such as cellulose, sucrose and korrigan (an endo-glucanase that is essential for proper cell wall formation) and one growth hormone (Table 4). A total of 27 gene fragments were studied. Fourteen gene regions are involved in the lignin biosynthesis, eight in lignin regulation as transcription factors, three in cellulose biosynthesis, one in sucrose biosynthesis and one in growth hormone regulation. The primers for these regions were developed from multiple species EST

Table 4 Gene regions assessed and their biochemical role

\begin{tabular}{|c|c|c|}
\hline Locus & $\begin{array}{l}\text { Phytozome gene } \\
\text { ID targeted }^{1}\end{array}$ & Role \\
\hline 4CL1prom & Not used & Lignin biosynthesis \\
\hline $4 C L 1$ & Not used & Lignin biosynthesis \\
\hline $4 C L 2$ & Potri.019G049500 & Lignin biosynthesis \\
\hline AP2 & Not used & Putative lignin regulation \\
\hline BHLH144 & Not used & Putative lignin regulation \\
\hline BZIP47 & Not used & Putative lignin regulation \\
\hline BZIP9 & Not used & Putative lignin regulation \\
\hline $\mathrm{C} 3 \mathrm{H} 1$ & Potri.006G033300 & Lignin biosynthesis \\
\hline $\mathrm{C} 4 \mathrm{H}$ & Potri.013G157900 & Lignin biosynthesis \\
\hline$C A D$ & Potri.009G095800 & Lignin biosynthesis \\
\hline CCOAOMT & Not used & Lignin biosynthesis \\
\hline$C C R$ & Not used & Lignin biosynthesis \\
\hline CesA1 & Potri.002G257900 & Cellulose biosynthesis \\
\hline CesA2 & Potri.005G194200 & Cellulose biosynthesis \\
\hline $\mathrm{F} 5 \mathrm{H}$ & Not used & Lignin biosynthesis \\
\hline$G A-20$ & Potri.015G134600 & Growth hormone \\
\hline $\mathrm{HCT}$ & Not used & Lignin biosynthesis \\
\hline Knat7 & Potri.001G112200 & Putative lignin regulation \\
\hline Kor1 & Potri.003G151700 & $\begin{array}{l}\text { Korrigan - endoglucanase cell } \\
\text { wall formation }\end{array}$ \\
\hline myb & Not used & Transcription \\
\hline Myb63 & Not used & Putative lignin regulation \\
\hline Mybr2r3 & Potri.015G033600 & Transcription \\
\hline PAL1 & Potri.006G126800 & Lignin biosynthesis \\
\hline PAL2 & Not used & Lignin biosynthesis \\
\hline PTOMT1 & Not used & Lignin biosynthesis \\
\hline$S A D$ & Potri.016G078300 & Lignin biosynthesis \\
\hline Sucrose synthase & Not used & Sucrose biosynthesis \\
\hline
\end{tabular}

${ }^{1}$ Based on P. trichocarpa v3 from Phytozome (http://www.phytozome.net/poplar). Details as in Kelleher et al. [17].
(Expressed Sequence Tag) alignments from $P$. tremuloides and P. trichocarpa [17].

\section{Amplification of target genes}

Primers from Kelleher et al. [17] were used for the amplification of 27 different gene regions of the nuclear genome. Primers were synthesized by Eurofins MWG Operon. A single PCR protocol was used to test all primers on every sample using a Biometra "TProfessional" thermal cycler. The PCR for a $10 \mu \mathrm{L}$ reaction was as follows: $10 \mathrm{ng}$ DNA, dNTPs at $0.2 \mathrm{mM}$, each primer at $2.5 \mathrm{ng} / \mu \mathrm{L}, \mathrm{MgCl}_{2}$ at 1.5 $\mathrm{mM}$ and 0.25 units of $\mathrm{GoTaq}^{\circ}$ DNA Polymerase from Promega (Madison, USA) and the parameters were: $94^{\circ} \mathrm{C}$ for $2 \mathrm{~min} ; 30$ cycles of : $94^{\circ} \mathrm{C}$ for $1 \mathrm{~min}, 58-60^{\circ} \mathrm{C}$ for $1 \mathrm{~min}$, $72^{\circ} \mathrm{C}$ for $1 \mathrm{~min} ; 72^{\circ} \mathrm{C}$ for $10 \mathrm{~min}$. The PCR products were stained with ethidium bromide and viewed over UV light after agarose gel electrophoresis.

\section{Cleaning and sequencing}

The desired amplicons were cleaned using the JET quick PCR product purification kit (Genomed), then resuspended in water. Cloning of several genes was required prior to sequencing (see below). Cycle sequencing reactions used the BigDye ${ }^{6}$ Terminator v3.1 kit and the manufacturer's protocols. The sequencing primers were the same as used for the PCR. Cycle sequencing products were cleaned following the ethanol precipitation protocol of Applied Biosystems. The samples were sequenced with an Applied Biosystems 3130xl Genetic Analyzer.

\section{Cloning}

Cloning was performed to resolve the unique sequences of alleles and orthologs for several of the genes including 4CL2, CAD, CesA1, GA-20, Knat7, Kor1, Mybr2r3 and $S A D$. Chemically competent XLI-blue strain Escherichia coli cells were prepared using a modified protocol from Inoue et al. [49]. PCR products were then inserted into plasmids using the CloneJET PCR cloning kit from Thermo Scientific and following the manufacturer's protocol. The transformed bacteria were left to grow overnight at $37^{\circ} \mathrm{C}$ on Luria-Bertani (LB) plates containing $50 \mu \mathrm{g} / \mathrm{mL}$ ampicillin. Eight colonies were then resuspended into LB and $1.5 \mu \mathrm{L}$ was used in a standard $15 \mu \mathrm{L}$ PCR mix using the same primers as the initial PCR amplification. Electrophoresis gels were used to confirm the presence of the insert. At least 4 colonies per transformation were then sequenced.

\section{Data analyses}

Sequences were analyzed for SNPs and insertions-deletions (indels), using Seqscape Version 2.6, software (Applied Biosystems). This software aligns and reports variations between the different samples. BLAST searches were made against the nucleotide database of the NCBI $[50,51]$ and against Phytozome (http://www.phytozome.net/poplar) to 
check similarity with existing database sequences. Alignments were made against Populus trichocarpa Phytozome gene models but were also compared with the best BLAST hits from other poplar accessions (Table 2). Phylogenetic reconstruction of the genes used in this study has been performed to test for possible paralogy. A gene family keyword search was performed into phytozome (www.phytozome.net/search.php) for each gene and $A$. thaliana and $P$. trichocarpa genes were retrieved and aligned to a consensus Salix sequence generated from our study. Midpoint rooted maximum likelihood trees were generated in PhyML (www.atgc-montpellier.fr/phyml/) with the HKY85+G substitution model (estimated gamma shape parameter and four substitution rate categories) and NNI branch swapping. Bootstrap values were generated using with 1000 replicates of the same model with NNI swapping.

Variation among Salix species was assessed by calculating: (SNPs/length) $\times 1,000$ over the consensus sequences obtained from the Seqscape alignments. Populus homologs were downloaded from GenBank and included in the analysis to test for variation between Salix and Populus and to assess inter species variation in the sister genera. The reading frame was determined using DnaSP version 5.10 [52]. Inference of haplotypes was carried out using Arlequin 3.5 [53]. Haplotype number in sequences obtained from the cloning step was also calculated in Arlequin 3.5.

Phylogenetic trees were generated in PAUP [54] with a maximum parsimony analysis or PhyML (http://www.atgcmontpellier.fr/phyml/) with maximum likelihood. Parsimony analyses used 1000 random addition sequences with TBR branch swapping. Parsimony bootstrapping was conducted with 1000 replicates and NNI branch swapping. Maximum likelihood analyses in PhyML were generated with the HKY85+G substitution model (as above) for the orthology testing. All trees were midpoint rooted.

Regression analysis in Excel was used to explore the relationship between DNA ploidy and number of SNPs/kbp on 20 Salix genotypes.

\section{Additional files}

Additional file 1: Details of the amplification results obtained from the loci and species studied from electrophoresis gels for the 27 gene fragments ( 0 : nothing has been amplified; 1, 2, 3, X: 1, 2, 3, multiple band(s)).

Additional file 2: Details of SNPs numbers per studied species per gene region compared to the Phytozome gene model used as reference (see Table 1).

\section{Abbreviations}

BLAST: Basic local alignments search tool; EST: Expressed sequence tag; NCBI: National Center for Biotechnology Information; PCR: Polymerase chain reaction; SNP: Single nucleotide polymorphism; SRC: Short rotation coppice.

\section{Competing interests}

The authors declare that they have no competing interests.

\section{Authors' contributions}

AP performed the experiments, analysed the data and wrote the paper. CK contributed to experimental design, analysis and writing of the manuscript. $\mathrm{TH}$ contributed to experimental design, analysis and writing of the manuscript. GD contributed to experimental design and writing of the manuscript. All authors read and approved the final manuscript.

\section{Acknowledgements}

We thank Dr. Matthew Jebb, Director of the National Botanic Gardens, Glasnevin, Ireland for sampling help. We also thank Patricia Coughlan, Siobhán McNamee and Prof. Desmond Higgins (University College Dublin) for technical support. We thank Dr Emmanuelle Graciet, Kamila Kwasniewska and Katarzyna Ma Hanczaryk for help with the cloning (Trinity College Dublin). We also thank Joe Hogan for freely giving us samples of material. The research is supported by a Walsh Fellowship PhD Grant from Teagasc, The Irish Agriculture and Food Development Authority.

\section{Author details}

${ }^{1}$ Teagasc, Agriculture and Food Development Authority, Kinsealy Research Centre, Malahide Road, Dublin, D17, Ireland. ${ }^{2}$ Botany Building, School of Natural Sciences, Trinity College Dublin, Dublin, D2, Ireland. ${ }^{3}$ DBN Plant Molecular Laboratory, National Botanic Gardens, Glasnevin, Dublin, D9, Ireland. ${ }^{4}$ Trinity Centre for Biodiversity Research, Trinity College Dublin, Dublin, D2, Ireland.

Received: 20 March 2013 Accepted: 2 August 2013

Published: 7 August 2013

\section{References}

1. Argus GW: Infrageneric classification of Salix (Salicaceae) in the New World. Syst Bot Monogr 1997, 52:1-121.

2. Newsholme C: Willows: the genus Salix. Illustratedth edition. London, UK: BT Batsford Ltd; 1992.

3. Styles D, Thorne F, Jones MB: Energy crops in Ireland: An economic comparison of willow and Miscanthus production with conventional farming systems. Biomass Bioenergy 2008, 32:407-421.

4. Styles D, Jones MB: Energy crops in Ireland: quantifying the potential life-cycle greenhouse gas reductions of energy-crop electricity. Biomass Bioenergy 2007, 31:759-772.

5. McLaughlin SB, Samson R, Bransby D, Wiselogel A: Evaluating physical, chemical, and energetic properties of perennial grasses as biofuels. In Bioenergy '96: Partnerships to Develop and Apply Biomass Technologies Proceedings of the Seventh National Bioenergy Conference; Nashville, TN, USA; 1996:1-8.

6. Davin LB, Lewis NG: Phenylpropanoid metabolism: Biosynthesis of monolignols, lignans and neolignans, lignins and suberins. In Phenolic Metabolism in Plants. Edited by Stafford HA, Ibrahim RK. New York: Plenum Press; 1992:325-375.

7. Douglas C: Phenylpropanoid metabolism and lignin biosynthesis: from weeds to trees. Trends Plant Sci 1996, 1:171-178.

8. Novaes E, Kirst M, Chiang V, Winter-Sederoff H, Sederoff R: Lignin and Biomass: a negative correlation for wood formation and lignin content in trees. Plant Physiol 2010, 154:555-561.

9. Humphreys JM, Chapple C: Rewriting the lignin roadmap. Curr Opin Plant Biol 2002, 5:224-229.

10. Taylor NG: Cellulose biosynthesis and deposition in higher plants. New Phytol 2008, 178:239-252.

11. Joshi CP, Mansfield SD: The cellulose paradox - simple molecule, complex biosynthesis. Curr Opin Plant Biol 2007, 10:220-226.

12. Tuskan GA, DiFazio S, Jansson S, Bohlmann J, Grigoriev I, Hellsten U, Putnam N, Ralph S, Rombauts S, Salamov A, et al: The genome of black cottonwood, Populus trichocarpa (Torr. \& Gray). Science 2006, 313:1596-1604.

13. Kelleher CT, Chiu R, Shin H, Bosdet IE, Krzywinski MI, Fjell CD, Wilkin J, Yin TM, DiFazio SP, Ali J, et al: A physical map of the highly heterozygous Populus genome: integration with the genome sequence and genetic map and analysis of haplotype variation. Plant Journal 2007, 50:1063-1078. 
14. Yin T, DiFazio SP, Gunter LE, Zhang X, Sewell MM, Woolbright SA, Allan GJ, Kelleher CT, Douglas CJ, Wang M, Tuskan GA: Genome structure and emerging evidence of an incipient sex chromosome in Populus. Genome Res 2008, 18:422-430.

15. Geisler-Lee J, Geisler M, Coutinho PM, Segerman B, Nishikubo N, Takahashi J, Aspeborg H, Djerbi S, Master E, Andersson-Gunneras S, et al: Poplar carbohydrate-active enzymes. Gene identification and expression analyses. Plant Physiol 2006, 140:946-962.

16. Jorge V, Dowkiw A, Faivre-Rampant P, Bastien C: Genetic architecture of qualitative and quantitative Melampsora larici-populina leaf rust resistance in hybrid poplar: genetic mapping and QTL detection. New Phytol 2005, 167:113-127.

17. Kelleher CT, Wilkin J, Zhuang J, Javier Cortes A, Pérez Quintero AL, Gallagher T, Bohlmann J, Douglas C, Ellis BE, Ritland K: SNP discovery, gene diversity and linkage disequilibrium in wild populations of Populus tremuloides. Tree Genet Genomes 2012, 8:821-829.

18. Berlin S, Lagercrantz U, von Arnold S, Ost T, Ronnberg-Wastljung AC: Highdensity linkage mapping and evolution of paralogs and orthologs in Salix and Populus. BMC Genomics 2010, 11.

19. Hanley SJ, Mallott MD, Karp A: Alignment of a Salix linkage map to the Populus genomic sequence reveals macrosynteny between willow and poplar genomes. Tree Genet Genomes 2006, 3:35-48.

20. Cukovic D, Ehlting J, VanZiffle JA, Douglas CJ: Structure and evolution of 4-coumarate : coenzyme A ligase (4CL) gene families. Biol Chem 2001, 382:645-654.

21. Djerbi S, Lindskog M, Arvestad L, Sterky F, Teeri $\Pi$ : The genome sequence of black cottonwood (Populus trichocarpa) reveals 18 conserved cellulose synthase (CesA) genes. Planta 2005, 221:739-746.

22. Meyermans H, Morreel K, Lapierre C, Pollet B, De Bruyn A, Busson R, Herdewijn $P$, Devreese B, Van Beeumen J, Marita JM, et al: Modifications in lignin and accumulation of phenolic glucosides in poplar xylem upon downregulation of caffeoyl-coenzyme A O-methyltransferase, an enzyme involved in lignin biosynthesis. J Biol Chem 2000, 275:36899-36909.

23. Barker JHA, Pahlich A, Trybush S, Edwards KJ, Karp A: Microsatellite markers for diverse Salix species. Mol Ecol Notes 2003, 3:4-6.

24. Przyborowski JA, Sulima P: The analysis of genetic diversity of Salix viminalis genotypes as a potential source of biomass by RAPD markers. Ind Crops Prod 2010, 31:395-400.

25. Barker JHA, Matthes M, Arnold GM, Edwards KJ, Ahman I, Larsson S, Karp A Characterisation of genetic diversity in potential biomass willows (Salix spp.) by RAPD and AFLP analyses. Genome 1999, 42:173-183.

26. Thibault J: Nuclear DNA amount in pure species and hybrid willows (Salix): a flow cytometric investigation. Can J Bot 1998, 76:157-165.

27. Meikle RD: Willows and poplars of Great Britain and Ireland. illustrated, reprint edn. Botanical Society of the British Isles: London, UK; 1984.

28. Loureiro J, Rodriguez E, Dolezel J, Santos C: Two new nuclear isolation buffers for plant DNA flow cytometry: a test with 37 species. Ann Bot 2007, 100:875-888

29. Guindon S, Dufayard J-F, Lefort V, Anisimova M, Hordijk W, Gascuel O: New algorithms and methods to estimate maximum-likelihood phylogenies: assessing the performance of PhyML 3.0. Syst Biol 2010, 59:307-321.

30. Stamati K, Blackie S, Brown JWS, Russell J: A set of polymorphic SSR loci for subarctic willow (Salix lanata, S-lapponum and S-herbacea). Mol Ecol Notes 2003, 3:280-282.

31. MacAlpine WJ, Shield IF, Trybush SO, Hayes CM, Karp A: Overcoming barriers to crossing in willow (Salix spp.) breeding. Aspects of Appl Biol 2008, 90:173-180.

32. Berlin S, Fogelqvist J, Lascoux M, Lagercrantz U, Ronnberg-Wastljung AC: Polymorphism and divergence in two willow species, Salix viminalis L. and Salix schwerinii E. Wolf. G3 (Bethesda, Md) 2011, 1:387-400.

33. Hanley SJ, Pei MH, Powers SJ, Ruiz C, Mallott MD, Barker JHA, Karp A Genetic mapping of rust resistance loci in biomass willow. Tree Genet Genomes 2011, 7:597-608.

34. Azuma T, Kajita T, Yokoyama J, Ohashi H: Phylogenetic relationships of Salix (Salicaceae) based on rbcL sequence data. Am J Bot 2000, 87:67-75.

35. Hardig TM, Anttila CK, Brunsfeld SJ: A phylogenetic analysis of salix (Salicaceae) based on matk and ribosomal DNA sequence data. J Bot 2010, 2010:

36. Trybush S, Jahodova S, Macalpine W, Karp A: A genetic study of a Salix germplasm resource reveals new insights into relationships among subgenera, sections and species. Bioenergy Res 2008, 1:67-79.
37. Brunsfeld SJ, Soltis DE, Soltis PS: Evolutionary patterns and processes in Salix sect. Longifoliae: evidence from chloroplast DNA. Syst Bot 1992, $17: 239-256$

38. Ingvarsson PK: Nucleotide polymorphism and linkage disequilbrium within and among natural populations of European Aspen (Populus tremula L., Salicaceae). Genetics 2005, 169:945-953.

39. Ingvarsson PK: Multilocus patterns of nucleotide polymorphism and the demographic history of Populus tremula. Genetics 2008, 180:329-340.

40. Pei MH, Lindegaard K, Ruiz C, Bayon C: Rust resistance of some varieties and recently bred genotypes of biomass willows. Biomass \& Bioenergy 2008, 32:453-459.

41. Suda $Y$, Argus GW: Chromosome numbers of some North American Salix. Brittonia 1968, 20:191-197.

42. Hamberger B, Ellis M, Friedmann M, de Azevedo Souza C, Barbazuk B, Douglas CJ: Genome-wide analyses of phenylpropanoid-related genes in Populus trichocarpa, Arabidopsis thaliana, and Oryza sativa: the Populus lignin toolbox and conservation and diversification of angiosperm gene families. Can J Bot 2007, 85:1182-1201.

43. Weng J-K, Chapple C: The origin and evolution of lignin biosynthesis. NeW Phytol 2010, 187:273-285.

44. Li L, Cheng XF, Leshkevich J, Umezawa T, Harding SA, Chiang VL: The last step of syringyl monolignol biosynthesis in angiosperms is regulated by a novel gene encoding sinapyl alcohol dehydrogenase. Plant Cell 2001, 13:1567-1586.

45. Ramsay $H$, Rieseberg LH, Ritland K: The correlation of evolutionary rate with pathway position in plant terpenoid biosynthesis. Mol Biol Evol 2009 26:1045-1053

46. Barakate A, Stephens J, Goldie A, Hunter WN, Marshall D, Hancock RD, Lapierre C, Morreel K, Boerjan W, Halpin C: Syringyl lignin is unaltered by severe sinapyl alcohol dehydrogenase suppression in tobacco. The Plant Cell Online 2011, 23:4492-4506.

47. Bomati EK, Noel JP: Structural and kinetic basis for substrate selectivity in Populus tremuloides sinapyl alcohol dehydrogenase. Plant Cell 2005, 17:1598-1611.

48. Eun HM: Enzymology Primer for Recombinant DNA Technology. San Diego: Academic press; 1996.

49. Inoue $\mathrm{H}$, Nojima $\mathrm{H}$, Okayama $\mathrm{H}$ : High-efficiency transformation of Escherichia-coli with plasmids. Gene 1990, 96:23-28.

50. Altschul SF, Gish W, Miller W, Myers EW, Lipman DJ: Basic Local Alignment Search Tool. J Mol Biol 1990, 215:403-410

51. Johnson M, Zaretskaya I, Raytselis Y, Merezhuk Y, McGinnis S, Madden TL: NCBI BLAST: a better web interface. Nucleic Acids Res 2008, 36:W5-W9.

52. Librado P, Rozas J: DnaSP v5: a software for comprehensive analysis of DNA polymorphism data. Bioinformatics 2009, 25:1451-1452.

53. Excoffier L, Laval G, Schneider S: Arlequin (version 3.0): An integrated software package for population genetics data analysis. Evol Bioinf 2005, $1: 47-50$.

54. Swofford D: PAUP*. Phylogenetic Analysis Using Parsimony $\left({ }^{*}\right.$ and other methods). Version 4. Sinauer Associates; 2002.

\section{doi:10.1186/1754-6834-6-114}

Cite this article as: Perdereau et al:: High levels of variation in Salix lignocellulose genes revealed using poplar genomic resources. Biotechnology for Biofuels 2013 6:114.

\section{Submit your next manuscript to BioMed Central and take full advantage of:}

- Convenient online submission

- Thorough peer review

- No space constraints or color figure charges

- Immediate publication on acceptance

- Inclusion in PubMed, CAS, Scopus and Google Scholar

- Research which is freely available for redistribution 